\title{
Crônicas de Caio Fernando Abreu: a subjetividade e a busca pelo diálogo com o leitor
}

\author{
Luana Teixeira Porto* \\ Larissa Bortoluzzi Rigo**
}

\section{Resumo}

Este trabalho examina crônicas do escritor Caio Fernando Abreu, publicadas no jornal Folha de São Paulo nas décadas de 1980 e 1990 e reunidas no livro A Vida Gritando aos Cantos, de 2012. A proposta consiste em identificar três peculiaridades da crônica do autor: a subjetividade, o trabalho de citação e a busca pelo diálogo com o leitor. A leitura e interpretação da crônica de Caio, neste trabalho recebe, como procedimento metodológico, a articulação da forma e do conteúdo das narrativas na perspectiva crítica da sociologia da literatura. Ao examinar crônicas de Caio, observa-se que, as narrativas do escritor gaúcho possuem como particularidades a oralidade e percepção de assuntos cotidianos, também estão inseridas em um profundo significado dos atos e sentimentos humanos, estabelecendo, assim, uma crítica social a partir de diálogos com o leitor, pois, quando o narrador incita o seu leitor a questionamentos, esse fica passível de refletir sobre as prerrogativas por meio da escrita literária.

Palavras-chave: Literatura. Crônica. Caio Fernando Abreu. Sociedade. Memória.
A crônica de Caio apresenta muitos traços importantes para serem considerados no processo de leitura e interpretação desse gênero narrativo. $\mathrm{O}$ autor mostra, em suas crônicas, uma narrativa em que o caráter autobiográfico dilui-se em meio a temas de representação social. O tom autobiográfico das crônicas do escritor, nessa perspectiva, não é um traço isolado dos textos cronísticos do autor, pois aparece na crônica brasileira.

No tocante ao caráter autobiográfico das crônicas brasileiras em especial, Simon (2008) argumenta que está relacionado à matiz memorialista, uma vez que, ao contar um fato ou explorar assuntos do cotidiano, o escritor precisa buscar em sua memória como ocorre a constituição desses:

\footnotetext{
Doutora em Letras e professora do Mestrado em Letras da URI, campus Frederico Westphalen. E-mail: luana@ uri.edu.br

** Mestre em Letras e professora da Universidade Federal de Santa Maria, campus Frederico Westphalen. E-mail: lary_rigo@yahoo.com.br
}

Data de submissão: mar. 2015- Data de aceite: maio 2015 http://dx.doi.org/10.5335/rdes.v11i1.5040 
Se é possível admitir a matiz memorialista nas crônicas e no seu conjunto, é também necessário conviver com o falseamento daqueles e de outros escritos que não se submetem à condição de reproduções fiéis dos fatos e sensações ali expostos (SIMON, 2008, p. 57). ${ }^{1}$

Além da presença do signo autobiográfico, atrelado à memória, as crônicas de Caio, com um toque de lirismo, também formam um diálogo aberto e explícito entre escritor, leitor e sociedade. $\mathrm{O}$ autor ainda explora em seus textos uma linguagem de aproximação com o leitor, para chegar aos que leem, como se estivessem em uma conversa diária, que aborda distintos temas, desde política, música, violência, cinema, histórias íntimas até televisão e novelas, dentre outros. A linguagem da sua crônica ainda se mostra uma linguagem paradoxal, que vai do nível culto ao coloquial, da escrita simples à redação mais exigente.

No que confere peculiaridades à linguagem, características formais, como simplicidade, qualidade textual, caráter urgente e sintético, coloquialismo elaborado e o caráter de atemporalidade - 0 que torna a memória como parte constitutiva do gênero -, estão presentes nas crônicas de Caio. As suas narrativas, de forma geral, apresentam uma tônica voltada ao social e, com as crônicas, essa premissa não é diferente. Caio utilizava seu espírito crítico, por vezes até mesmo sendo autocrítico, para abordar temas que cercavam a sua geração.
Considerando seu espírito crítico, induzindo o leitor à reflexão e a temas que remetem ao cotidiano, o objetivo desta reflexão é observar, na obra A Vida Gritando nos Cantos, uma das peculiaridades que pontuam a crônica do escritor gaúcho: a linguagem coloquial, já que observar a linguagem dos textos é uma forma de conhecer melhor a tônica dos temas e o diálogo que as narrativas estabelecem com seus leitores e contexto social.

O livro reúne crônicas publicadas por Caio no "Caderno 2" do jornal O Estado de São Paulo, em diferentes períodos. Nessa obra, as crônicas estão separadas por três partes e em sequência cronológica: a primeira é composta pelas que foram produzidas de 1986 a 1988 , a segunda compreende os anos de 1993 a 1996, e na terceira estão aquelas sem data. Desse modo, para a subjetividade, o trabalho de citação nas crônicas e a busca pelo diálogo com o leitor, passamos a demonstrar essa característica, por meio de exemplos das crônicas.

\section{A subjetividade e o trabalho de citação nas crônicas}

O tom íntimo e coloquial utilizado por Caio nas crônicas é uma de suas marcas na escrita desse gênero. Contudo, há também várias referências a autores e obras que sinalizam um intenso trabalho de citação nas crônicas do escritor. Nesse contexto, o leitor tem uma importante 
tarefa: estar preparado para a compreensão dos elementos externos ao texto que são citados pelo autor. Acerca desses elementos externos, entendemos que Caio utiliza em suas narrativas o que Antoine Compagnon, na obra $O$ trabalho da citação, compreende como citação.

Para o estudioso, a citação pode ser comparada ao processo arcaico e lúdico de recortar e colar, do mesmo modo que essa brincadeira é feita, o escritor utiliza os elementos que "recorta" em seus textos. É nesse sentido que o autor afirma: "a citação trabalha o texto, o texto trabalha a citação" (COMPAGNON, 2007, p. 46). Além disso, o contexto também deve ser analisado nesse processo: "A citação não tem sentido em si, porque ela só se realiza em um trabalho, que a desloca e que a faz agir" (COMPAGNON, 2007 , p. 47). Com vistas à perspectiva segundo a qual ocorre um cruzamento de vozes na construção literária, o diálogo incorre na medida em que a obra e a sociedade fazem parte dessa ótica, justamente o que pode ser verificado em Caio. $\mathrm{O}$ autor utiliza elementos de citação em seu texto que estão inseridos sob o viés de um contexto externo, que precisa ser compreendido pelo leitor.

Por esse processo de compreensão, Compagnon (2007) entende que há quatro figuras distintas para o processo de leitura: ablação, grifo, acomodação e solicitação. A primeira estaria relacionada a extrair uma parte importante do texto, o grifo é um processo que coloca marcas ao texto, conforme relata o estudioso: "o grifo na leitura é a prova preliminar da citação (e da escrita), uma localização visual, material que institui o direito do meu olhar sobre o texto. Tal como o reconhecimento militar o grifo coloca marcas" (COMPAGNON, 2007, p. 19). No tocante à acomodação, o autor a transpõe para um lugar de reconhecimento, já que se refere a uma marca de leitura:

Dentre as numerosas definições em torno da citação, proporemos esta: a citação é um lugar de acomodação previamente situado no texto. Ela integra em um conjunto ou em uma rede de textos, em uma tipologia das competências requeridas para a leitura; ela é reconhecida e não compreendida, ou reconhecida antes de ser compreendida (COMPAGNON, 2007, p. 22).

Após retirar a parte importante do texto, grifar e marcar, a solicitação é compreendida como o retalhamento das narrativas. $\mathrm{O}$ autor explica:

Ela [solicitação] limitar-se-ia ao namoro, deixaria de excitar, de retalhar o texto. Seria, sem dúvida, uma interpretação, assim como uma única leitura concebível da enunciação. A solicitação é o correspondente, em leitura, da enunciação, um acomodamento, uma conciliação do enunciado. E as marcas da solicitação no texto são as excitações, os grifos, os desmembramentos: sinais sempre aproximativos e insatisfatórios, mas presunções de uma verdade que foi, instantaneamente, a da minha leitura (COMPAGNON, 2007, p. 26).

Com vistas à aproximação que esses quatro processos possuem, Compagnon (2007) elucida que não necessariamente se sucedem, mas sim podem realizar-se uns nos outros: 
Todavia, há entre elas uma degradação latente, uma ordem teórica, inversa daquela em que foram descritas e que, partindo da mutilação, penetrava até o intratável da paixão pela leitura, onde se perdia. Elas partem do objeto total em que é para mim o texto que me encanta na solicitação, passam pela acomodação num lugar reconhecido de satisfação, pelo grifo que aprisiona esse lugar, e alcançam o objeto parcial que destaco do texto na ablação. Trata-se através desses quatro momentos, de uma aproximação cada vez mais fina, de um quadriculado estratégico. Mas esse não tem nada a ver com a significação (COMPAGNON, 2007, p. 27).

Por significação o autor compreende como sendo o quinto processo a que a leitura está relacionada:

Eu recorro ao sentindo como a um último recurso, agarro-me a ele por não poder encontrar a paixão, na ilusão desesperada de que um esforço sobre a significação prender-me-ia ao texto, que pela solicitação, não me prendeu (COMPAGNON, 2007, p. 28).

A solicitação, nesse contexto, faz parte ao valor que é atribuído ao texto. E após a ela, o estudioso cita a excitação visto que destaca o sentido da solicitação. $\mathrm{Na}$ esteira entre a solicitação e a excitação, encontra-se a citação. Compagnon (2007) esclarece que a citação,

Está no princípio de toda leitura, pelo menos daquela que, impotente, prende-se exclusivamente à significação. A citação tenta reproduzir na escrita uma paixão pela leitura, reencontrar a fulguração instantânea da solicitação, pois é a leitura, solicitadora e excitante, que produz a citação. A citação repete, faz com que a leitura ressoe na escrita: é que, na verdade, leitura e escrita são a mesma coisa, a prática do texto que é prática do papel. A citação é a forma original de todas as práticas do papel, o recortar-colar, e é um jogo de criança (COMPAGNON, 2007, p. 29).
O estudioso distingue várias "modalidades" de citação e defende a ideia de que estas por si só, são provocativas para o leitor, oferecem pistas de como realizar a leitura: "Ela marca um encontro, convida para leitura, solicita, provoca como uma piscadela: é sempre a perspectiva do olho que se acomoda, do olho que se supõe na linha de fuga da perspectiva" (COMPAGNON, 2007, p. 23). Com efeito, quando o autor cita, os leitores são levados a outros lugares, ampliando, assim, a visão de leitura acerca das obras. Além disso, o autor destaca ser necessário não apenas identificar o trabalho de citação em um texto, mas especialmente identificar o sentido que essa citação confere ao texto escrito.

Conforme o viés apresentado acerca do conceito de citação, é possível inferir que o leitor precisa compreender que os elementos externos aos textos auxiliam na melhor compreensão das obras. Nesse sentido, Compagnon (2007) destaca que o trabalho de citação no ato de leitura exige uma competência leitora:

A citação é um operador trivial de intertextualidade. Ela apela para a competência do leitor, estimula a máquina da leitura, que deve produzir no trabalho, já que, numa citação, se fazem presente dois textos cuja relação não é de equivalência, nem de redundância. Mas esse trabalho depende um fenômeno imanente ao sentido conduzindo a leitura, porque há um desvio, ativação de sentido: um furo, uma diferença de potencial, um curto-circuito. $\mathrm{O}$ fenômeno é a diferença, o sentido é a sua resolução (COMPAGNON, 2007, p. 58-59).

Por esse prisma, somente um leitor preparado entenderá o processo de cita- 
ção, assim, a figura do leitor passa a ser considerada como destaque. O estudioso Umberto Eco parte da premissa de que o processo interpretativo se compõe de uma tríade que é formada entre autor-texto-leitor. Nessa esteira, será o leitor quem deverá fazer um recorte sobre as estratégias textuais que o autor coloca em seus textos. Assim, o leitor, chamado de ideal/modelo, vê a necessidade do reconhecimento de sua interpretação como elemento importante para fazer uma boa leitura.

Tais perspectivas estão atreladas nas crônicas de Caio em diferentes formas: em "Beta, beta, Bethânia", por exemplo, sem o conhecimento prévio das citações, não é possível compreender a mensagem do narrador. Nessa crônica, que foi publicada em 11 de fevereiro de 1987, o narrador explicita a sua afinidade com relação às músicas de Maria Bethânia. Podemos apontar a presença dos elementos externos ao texto por meio do fragmento:

Os muito darks que me perdoem, mas Maria Bethânia é fundamental. Sei, vocês vão dizer que ela é brega, careta, exagerada, melodramática. Pode ser. Mas essa coisa chamada vida, onde estamos metidos até o pescoço, às vezes também não é brega, careta, melodramática? A vida é mais Nelson Rodrigues ou mais Clarice Lispector? Mais Augusto dos Anjos ou Emily Dickinson? Fassbinder ou Jacques Demy? Philip Glass ou DeadKennedys? Mias Sex Pistols ou mais Cecília Meireles? Bukowsi ou Bergman? (ABREU, 2012, p. 78).

A primeira frase desse excerto apresenta uma alusão a um dos versos da poesia, Receita de Mulher, de Vinicius de
Moraes, quando esse poeta declara que "as feias que me perdoem, mas beleza é fundamental". A citação indireta desse verso na crônica de Caio se manifesta em dois níveis: o primeiro é linguístico, já que a sintaxe do texto original é mantida; e o segundo é conteudístico, pois, assim como o sujeito-lírico de Moraes defende a beleza mesmo sabendo da existência de mulheres feias, o narrador da crônica de Caio defende a música de Maria Bethânia mesmo sabendo que um tipo especial de público, os darks, não se identificam com o estilo musical da cantora. Esse reconhecimento da citação só é possível na medida em que o leitor da crônica de Caio mobiliza seu conhecimento prévio e se propõe a refletir sobre o sentido que tal citação acarreta ao texto.

Além disso, é possível destacar que, na medida em que o narrador cita desde cantores até escritores, eles tem um sentido para estar em seu texto, isto é, estão atrelados a diferentes momentos de sua vida. Essa premissa pode ser verificada no trecho:

Tudo isso, sim, e muito mais. O engarrafamento às seis da tarde de uma sexta-feira de chuva, na marginal do Tietê, pode ser uma emoção-Titãs (tipo "Bichos escrotos"). Transar com a garota prostituta da rua Augusta, de minissaia de couro e correntinha no tornozelo, pode ser uma emoção-Dalton Trevisan. Dar um espirro bem na hora de dizer eu-te-amo pode ser uma emoção-Woody Allen. Assim por diante, cada coisa sendo por cada um é tão particular que, mesmo lugar-comum ou já cantado em prosa e verso, é para sempre também único. Infinitiva e indivizivelmente subjetivo (ABREU, 2012, p. 78). 
O fragmento viabiliza um primeiro conjunto de observações. Um primeiro ponto diz respeito à forma com que Compagnon (2007) reconhece as citações. Para o estudioso, a citação por excelência é a epígrafe, e, além dessa, há a citação por aspas e a bibliografia. A recorrência das citações na narrativa de Caio se dá com a utilização da bibliografia e das aspas, e um exemplo de como incorre o emprego da primeira é a menção do fragmento supracitado que remete às músicas e aos cantores. O crítico explica esse recurso da seguinte forma:

Assim como uma cidade (mais urbana que celeste: uma pessoal moral), o texto é cercado por todos os lados. Ao pé da muralha, um fosso reduplica e acentua a fronteira; ele é sinalizado com postes e marcos; barreiras policiais vigiam as entradas: são as referências exibidas, as notas de rodapé foot-notes, em inglês. A todo instante elas trazem à lembrança aquilo sobre o que o texto se apoia, muletas ou estacas, aduelas: o texto é uma ponte lançada no vazio, do que tem horror; ele teme a queda. Entre seus pilares, [estão] a epígrafe e a bibliografia (COMPAGNON, 2007, p. 124).

Por essas vias, entendemos a bibliografia - como a metáfora utilizada pelo estudioso - o pé de uma montanha que é sinalizado por postes e marcos, então esses seriam os elementos externos, que se incorporam ao texto, proporcionando a sua sustentação, exatamente como a inclusão da bibliografia na narrativa de Caio é utilizada. Nesse sentido, a referência à música dos Titãs, na crônica "Beta, beta, Bethânia", configura-se como uma bibliografia, isto é, um elemento externo que é citado ao texto.
Para que o leitor entenda o que está sendo exposto pelo narrador, ele precisa ter conhecimento que a música "Bichos escrotos" do Titãs fala sobre baratas, ratos e lixos. Além disso, é preciso saber que a marginal Tietê é uma avenida da cidade de São Paulo que passa ao lado do rio Tietê. Este rio tornou-se conhecido em todo país pelas constantes divulgações na mídia acerca de sua poluição e sujeira. Por isso, o narrador, ao citar a música, está fazendo menção de que, em dias de chuva, a sujeira se intensifica e, nesse ambiente de sujeira, putrefação e decomposição de matéria-orgânica, todos decorrentes dos resíduos, acarretam ainda mais um ambiente favorável para a proliferação de animais, que se utilizam dos entulhos que se formam nos rios para construir seu habitat. Outros elementos externos ao texto são citados por meio da presença de Dalton Trevisan e Woody Allen. Sobre o primeiro, Soerenseet al (2012), afirmam:

Dalton Trevisan é um dos maiores contistas brasileiros. O autor utiliza o conto, que faz parte do gênero de narrar, para trazer à tona a reflexão sobre o cotidiano. É uma sequência de fatos corriqueiros que se caracteriza pela presença de ações, pela ocorrência de personagens prosaicas e por se referir a acontecimentos ordenados, na maioria das vezes, cronologicamente (p. 207).

Ao reconhecer acerca do que as autoras explanam sobre Dalton Trevisan, é possível verificar qual a interação entre a citação do narrador, quando diz "transar com a garota prostituta da rua Augusta, de minissaia de couro e correntinha no tornozelo, pode ser uma emoção- 
-Dalton Trevisan" (ABREU, 2012, p. 78). $\mathrm{O}$ narrador está referindo às temáticas utilizadas pelo autor paranaense, já que esse se dedica ao fazer literário sem concessões às distrações da vida pessoal $\mathrm{e}$ social e, nesse sentido, podemos afirmar que, sem o conhecimento prévio acerca das temáticas utilizadas por Trevisan, não seria possível compreender a citação do narrador. Em sentido análogo, ocorre a referência a Woody Allen, que é o nome artístico de Allan Stewart Königsberg, um cineasta, roteirista, escritor, ator e músico estadunidense, que no excerto é relacionado pelo narrador a sua forma de fazer cinema.

Ainda nesse aspecto, é possível inferir que os elementos supracitados, que são encontrados no texto de Caio, estão relacionados ao processo produtivo do escritor. Esse trabalho da escrita realizado pelo narrador pode ser melhor compreendido com base na explicação de Compagnon (2007):

O trabalho da escrita é uma reescrita já que se trata de converter elementos separados e descontínuos em um todo contínuo e coerente, de juntá-los, de compreendê-los (de tomá-los juntos), isto é, de lê-los: não é sempre assim? Reescrever, reproduzir um texto a partir de suas iscas, é organizá-las ou associá-las, fazer as ligações ou transcrições que se impõem entre os elementos postos em presença um do outro: toda escrita é colagem e glosa, citação e comentário (p. 39).

Nesse sentido, o estudioso afirma que escrever é sempre um ato de re-escrever, visto que, os elementos externos ao texto - as citações - diluem-se em meio às ideias de quem está nesse ato de es- crita, construindo assim, um novo texto que mescla essas diferentes alusões. Voltando à crônica, além desse trabalho de recriação por parte do narrador, identificamos outros signos: a melancolia, a subjetividade e a introspecção, todos ligados à citação da música (referenciada na crônica por Titãs), da Literatura (Dalton Trevisan) e do cinema (Woody Allen):

Darks, pós-modernos, minimalistas, gliters, apocalípticos, concretistas, skinheads, me perdoem. Na noite de sábado, caminhando sozinho pela avenida Paulista, o quarto-crescente brilhando sobre a torre da TV Globo, uma vontade desesperada de ter alguém - as únicas canções que me vieram à mente para cantar baixinho foram canções de Bethânia. Doía fundo estar perdido na grande cidade, era completamente sem remédio ser só uma pessoazinha machucada. Mas brotou então um orgulho tão grande de ser ainda capaz de sentir o coração cheio de emoções-Bethânia que era quase como uma felicidade. Sangrada, do avesso - que importa? Era real, era vivo. Isso é muito, e Bethânia canta (ABREU, 2012, p. 79).

O narrador novamente faz menção ao excerto de Vinícius de Moraes, Receita de Mulher, ao afirmar que os "Darks, pós-modernos, minimalistas, gliters, apocalípticos, concretistas, skinheads, me perdoem" (ABREU, 2012, p. 79). Nesse sentido, o leitor precisa estar preparado para entender o trabalho dessa citação. À medida que o narrador cita esses grupos sociais, está fazendo menção que nenhum tem preferência musical por Maria Bethânia e esse é um dos motivos pelos quais está se desculpando e já os avisa que irá cantar. Nessa esteira, o leitor precisa também ter conhecimento prévio sobre 
Maria Bethânia, isso porque é por meio do seu estilo musical - mais romântico e introspectivo - que o narrador se utiliza para preencher a sua "quase felicidade", e denotar seu estado de espírito.

Já em outras crônicas, como a "Por falar em estrelas", publicada em 14 de agosto de 1986, a figura do leitor também não é de passividade com relação à interpretação dos intertextos, contudo, o narrador deixa essas citações de forma clara, o que corrobora para que o contexto não tenha tanta relevância, quanto na crônica anterior. A narrativa da crônica citada, de forma geral fala sobre a paixão do narrador pela astrologia. Para confirmar que é uma ciência séria, ele cita algumas fontes, como por exemplo:

O que seria, então? Bom, se a astrologia fosse pura idiotice, você acha que Fernando Pessoa teria sido astrólogo? Aliás, a chave - ou uma das - para a compreensão de seus heterônimos está justamente nos mapas astrais que o danado levantou dos próprios. Para quem entende do negócio, faz muito sentido saber que Ricardo Reis tinha Mercúrio, Urano, Lua e Júpiter na casa 8 - a casa das transformações, da transcendência. Ainda nessa linha: Anais Nin, escritora brilhante, também era astróloga (e psicóloga). E Milan Kundera, veja só, é outro (ABREU, 2012, p. 39).

Como podemos perceber, a presença de elementos externos torna-se como na primeira crônica, evidente. No entanto, os escritores/astrólogos, Fernando Pessoa, Anais Nin e Milan Kundera não implicam a determinação da interpretação do leitor acerca da crônica. Mesmo sem conhecer as suas biografias, o leitor tem informações no texto de Caio para que eles sejam reconhecidos e entendidos.
Esses aspectos podem ser melhor explorados, com o excerto da narrativa em que o narrador explica a diferença entre astrologia e horóscopo de jornal:

$O$ problema é que as pessoas confundem astrologia com horóscopo de jornal. E não há nada mais pessoal que um mapa astral, o retrato do céu no momento em que nascemos. O horóscopo de jornal considera apenas a posição em que estava o Sol, ou o ascendente (a constelação do Zodíaco que subia no horizonte no momento do nascimento) e isso é vago demais. Em certos casos - como no horóscopo do Caderno 2, o de Hollander, na Folha, ou o de Pedro Tornaghi, no Around as informações mais sérias. E mesmo assim, vagas. Para fazer uma previsão astrológica, é preciso considerar trânsitos, progressões, revoluções, direções (ABREU, 2012, p. 39).

Mesmo sem ter o conhecimento prévio do Caderno 2, Hollander ou de Pedro Tornaghi do Around, o leitor pode entender que o narrador está citando elementos externos ao texto para explicar a diferença entre um horóscopo e o zodíaco. Além desse tipo de citação - a bibliográfica - nessa crônica há a ocorrência da utilização das aspas:

E para quem quiser ficar atento, deixo de saideira este trecho (citado de memória) de DorisLessing, em Shikasta: "Todos nós fazemos parte das estrelas. Elas nos fazem, nós as fazemos. Somos parte de uma estranha coreografia da qual nunca, de maneira alguma, podemos pensar em nos separar" (ABREU, 2012, p. 40).

Com a utilização das aspas, o narrador está mencionando de forma direta um elemento estranho ao seu texto, esse elemento é a citação por aspas. Compagnon (2007) a define como: 
O que as aspas dizem é que a palavra dada a um outro, que o autor renuncia a enunciação em benefício de um outro, as aspas designam uma re-enunciação, ou uma renúncia a um direito de autor. Elas operam uma sutil divisão entre os sujeitos e assinalam lugar em que a silhueta do sujeito da citação se mostra em retirada, como uma sombra chinesa (p. 52).

Desse modo, citando, o narrador faz com que um extratexto interfira na escrita, perfazendo uma nova enunciação que se mistura a ideia de outrem às explicações do novo texto, conduzindo assim o leitor a um mundo mais extenso. Com esteio nas ideias apresentadas, é oportuno ressaltar que, mesmo com as diferenças que foram expostas, as crônicas possuem uma coordenada em comum: o leitor é figura ativa. Por meio das narrativas pode-se refletir sobre o Leitor-Modelo que Caio espera de seus textos. Com base em seu estilo de linguagem e a forma com que conduz suas narrativas, podemos inferir que o Leitor-Modelo ${ }^{2}$ de Caio deve ter conhecimentos sobre elementos que contenham significação fora de seus textos. Nesse contexto, o narrador precisa da colaboração do leitor, no sentido de o primeiro deixar pistas para serem apreendidas, o que estiver implícito precisa ficar claro para o leitor. Por exemplo, quando lemos, "o filho de dona Matilde tornou-se médico", o que está implícito, pois o autor deixa pistas para o leitor, é que dona Matilde é a mãe, e que o filho dela é um homem, um ser vivo, que respira, etc. Nessa perspectiva de leitura, podemos entender que Eco volta-se para a reflexão de que ler vai além da perspectiva de compreender o que o texto diz, visto que ler é observar as implicaturas, aquilo que não está dito no texto:

[...] O trabalho do leitor é duplo: ao mesmo tempo que deve expandir certos termos, deve reduzir outros: amplia algumas propriedades, ao mesmo tempo que mantém outras sob narcose (ECO, 1979, p. 91).

Nessa esteira, percebemos que a atribuição de sentido a um texto ocorre na medida em que as hipóteses interpretativas são realizadas pelo Leitor-modelo. Esse leitor pode até não existir, mas o autor, de acordo com Eco, precisa trabalhar seu texto para construí-lo. Por si, o texto é visto como um sistema isolado, enquanto não estiver inserido, correlacionado a um objeto, perderá o sentido. Mesmo com a utilização de um dicionário para identificar o significado das palavras, não solucionará a questão, pois sempre há propriedades semânticas que permanecem implícitas. Outro fator que contribui para essas características citadas pelo autor é que a comunicação de um texto não ocorre frente a frente entre leitor e autor, de forma a obter perguntas/respostas, e, com vistas a isso, é que o leitor precisa cooperar: "O texto é um produto cujo destino interpretativo deve fazer parte do próprio mecanismo gerativo" (ECO, 1979, p. 39).

Por interpretação, Eco (1979) entende que a sua noção, "sempre envolve uma dialética entre estratégia do autor e resposta do Leitor-Modelo" (p. 43). O autor advoga ainda que a interpretação pressupõe um recorte, que é determinado pe- 
las estratégias textuais entre autor, texto e Leitor-Modelo, assim, a interpretação deve ser vista como um processo aberto e cooperativo pela tríade autor-texto-leitor. É com base nas inter-relações formadas por autor e leitor que os diálogos nas crônicas de Caio estão pautadas, haja vista também o intenso trabalho de citação que é perceptível nas crônicas do autor e que mobilizam o conhecimento prévio do leitor na construção de sentido para as crônicas. É sobre a busca pelo diálogo com o leitor que a próxima seção trata.

\section{A busca pelo diálogo com o leitor}

Uma particularidade da crônica que lhe confere importância está calcada no processo que busca a manifestação da oralidade na escrita, isto é, deixa de ser um comentário argumentativo ou expositivo para se tornar uma espécie de conversa entre narrador e leitor. No que tange ao leitor, é importante ressaltar que o leitor de jornal não é uma unidade abstrata, visto que o meio impresso se dirige a um público-alvo, dessa forma, o jornalista/cronista, sabe - de forma generalista, mas não abstrata - a quem está escrevendo e quais os interesses desses leitores ${ }^{3}$. Nesse sentido, torna-se mais fácil para o narrador manter uma espécie de diálogo com os seus leitores. E é sobre esse processo de diálogo entre narrador/leitor que observaremos nas crônicas de Caio.
A crônica publicada em seis de abril de 1986 "Para machucar corações" está atrelada a um dos assuntos preferidos do escritor gaúcho em suas crônicas: a música. Com vias a comentar o disco do músico John Lennon, o narrador mescla reflexões do dia a dia em uma cidade movimentada: "Aquela fadiga que se insinua, persistente, entre o ruído das buzinas e das descargas nos engarrafamentos de trânsito, todo dia" (ABREU, 2012, p. 17). A música, no contexto de cidade grande, pode ser entendida como uma fuga dos motoristas que precisam enfrentar os problemas citados pelo narrador.

Além do assunto principal - música -, o diálogo com o leitor é frequente em toda crônica, como pode ser observado, na linha de apoio ${ }^{4}$ da crônica: "Para quem tem mais de trinta, trinta e cinco anos, este disco pode ser uma tortura. Não, não é que seja um mau disco. Eu explico. Ou melhor tento" (ABREU, 2012 , p. 17). Esse fragmento constitui uma espécie de orientação de leitura que apresenta pistas ao leitor sobre o conteúdo da crônica. Podemos relacionar a linha de apoio ao hibridismo que as crônicas têm com a literatura e o jornalismo, já que esse elemento está presente em grande parte das 109 crônicas que estão reunidas na obra escolhida para compor o corpus dessa pesquisa, A Vida Gritando nos Cantos.

Além da presença dessa orientação de leitura, a opinião do narrador fica evidente. Sobre esse aspecto, Simon (2008) explica que, nas crônicas, o espaço do que 
o "eu" enxerga está atrelado à condição de narrador:

A crônica que funde acontecimento e comentário do acontecimento é propícia como espaço para aquilo que o "eu" vê, para o que o "eu", desdobrando-se em seguida para a expressão dos sentimentos, comentários e reflexões face ao que foi - às vezes, muito brevemente - narrado (p. 62).

Tomando como referência a proposição do autor, o narrador reproduz na crônica a sua visão acerca do que o disco de John Lennon acarreta no meio social. Nesse sentido, o narrador intui a busca por um diálogo, já a marca do discurso pode ser observada em fragmentos: "É que fatalmente eu/tu/ele/nós vamos lembrar" (ABREU, 2012, p. 17). O narrador inclui dessa forma o leitor, deixando-o como parte integrante da situação que é construída por ele (o narrador): "Eu não estou certo se essas lembranças serão boas. $\mathrm{Ou}$ se seria boas, lembradas hoje, você me entende?" (ABREU, 2012, p. 17). Mesmo sem possuir as marcas do narrador e o rompimento da convenção do discurso com relação à marcação das falas por aspas ou travessões, quando o narrador afirma "você me entende?", percebemos a presença de uma espécie de diálogo.

Em leitura análoga, uma das premissas presentes nas crônicas de Caio é o diálogo que suprime a presença do narrador. Há um rompimento de convenção do discurso, as falas são marcadas por expressões, sem a pontuação correta $\mathrm{e}$ sem a marcação para o leitor da mudança de quem fala. Essa observação pode ser exemplificada pelo fragmento:
Ele foi gravado ao vivo, no Madison Square Garden, em 30 de agosto de 1972. Há quase, portanto, catorze anos. Você tinha quantos quinze, vinte, vinte e cinco? E provavelmente também imaginava que, um dia, pudesse não haver mais guerras, nem países, nem ódio entre as pessoas. Um mundo novo, não é isso? (ABREU, 2012, p. 17-18).

Ao contextualizar os leitores da crônica acerca do período em que o disco de John Lennon foi produzido, o narrador, em formato de indagações, reporta-se aos leitores, observando um possível questionamento àqueles que estão lendo a crônica. $\mathrm{O}$ rompimento da convenção de discurso fica evidente neste diálogo, haja vista que, ao mesmo tempo em que o narrador pergunta, já coloca supostas respostas que os leitores lhe poderiam inferir. Essas afirmações ficam evidentes quando o narrador questiona: "Você tinha quantos - quinze, vinte, vinte e cinco?" E após, ainda, faz uma reflexão do meio social, denotando, que, com essa idade, as pessoas sonham com um mundo melhor. Nesse sentido, entendemos, além do rompimento da convenção de discurso, um cuidado especial para inserir o leitor em uma espécie de diálogo.

Essas mesmas marcas podem ser notadas em outras crônicas de Caio, como em "Inútil pranto por Santa Tereza", em que o narrador conta, em formato autobiográfico, a sua história com a cidade de Santa Tereza. Nessa crônica, o diálogo com o leitor está explicitando a incorporação de representar a violência que está ocorrendo nas cidades. Os tons de diálogos são mais reflexivos e menos diretos do que em "Para machucar cora- 
ções". A marca dessa premissa pode ser verificada no trecho a seguir:

Nos fundos do apartamento, um abismo de bananeiras, flores tropicais e selvagens que ninguém sabe o nome. Vezenquando alguma sobra atravessa a rua, bem natural. E nós tão hippies, mas tão hippies que volta e meia, geralmente nos sábados à tarde, o pintor Luiz Jasmin (onde andará?), que morava ao lado, colocava as caixas de som na janela e a trilha sonora de Hair bem alto, só para nós. Os acordes de Aquaris ou Letthesunshine in eram uma declaração de simpatia ao mesmo tempo explícita e delicada. Se éramos felizes? Não sei, éramos jovens (ABREU, 2012, p. 217).

A indagação sugestiona a introspecção do narrador por meio de lembranças íntimas com o morro de Santa Tereza. Já a representação do real pode ser observada no último parágrafo, em que o narrador finaliza sua narrativa, após descrever as recordações sobre a cidade de Santa Tereza:

Agora acabou. O que leio nos jornais e vejo na TV nas últimas semanas me deixa doente. Ainda mais doente. Santa Tereza sangra, transformada em Sarayejo tropical, em Chechênia invadida, estuprada. As pessoas abandonam as casas e fogem para qualquer lugar, escondendo o rosto. Balas perdidas cruzam o ar. Não, não sei se é suficiente chorar o que se perdeu e rezar pelo que ficou. Sei que, por conta disso, acabei achando um pouco ridículo $\mathrm{FHC}$ todo sorridente ao lado da rainha da Inglaterra e todas essas comemorações do fim da Segunda Guerra, enquanto Santa Tereza agoniza, desamparada e bela, no alto daquele morro. Quem pode fazer alguma coisa, que faça. E quem pode? (ABREU, 2012, p. 218).

Esse fragmento, mesmo sem a marca incisiva do diálogo, como foi demonstrado em outros trechos das narrativas de Caio, demonstra de forma clara que o recurso do diálogo, inclusive, presta-se para reforçar a ideia de que, mesmo sem as marcas discursivas, o narrador apresenta suas ideologias, suas interpretações frente ao leitor que passa a comungar de seus sentimentos. Ainda é oportuno ressaltar que, por meio dessa descrição que envolve até mesmo FHC (Fernando Henrique Cardoso, que era atual Presidente do Brasil na época em que a crônica foi escrita), sugestiona como se Caio questionasse os leitores sobre suas ideologias acerca da violência: como Santa Tereza, um lugar, que de acordo com suas descrições na crônica, transparecia ser tão calmo, e foi se transformando? Seu último questionamento, "e quem pode?" denota a sua preocupação com o social, não somente com Santa Tereza, mas sim com a violência em geral. Nesse sentido, podemos relacionar até mesmo o título da crônica: Inútil por Santa Tereza, desde a empregabilidade desses termos, identificamos uma perspectiva melancólica e pessimista sobre esse espaço urbano a qual é compartilhada com os leitores. Assim como na crônica anterior em que quatro amigos são utilizados para representar os jovens como em um todo, Santa Tereza é empregada como um dos exemplos sobre a violência que atinge a sociedade brasileira.

Ademais, o contexto externo utilizado pelo narrador que é sinalizado por meio de Sarayevo e Chechênia - duas regiões onde ocorrem conflitos armados -, introduzidas na narrativa para provocar a reflexão acerca do meio social. Caio estava atento à realidade externa e às 
semelhanças dessa com o contexto local, e isso pode ser evidenciado na medida em que o narrador da crônica demonstra que considerava inadequado, diante de um Brasil sangrento, haver a imagem de um Presidente sorridente, que indica despreocupação e até indiferença com a triste realidade brasileira, exemplificada por Santa Tereza.

A relação de hibridismo que a crônica tem com a literatura e o jornalismo elucida a forma com que Caio se utiliza do espaço que lhe é concedido no segmento editorial dos jornais para escrever suas crônicas. A forma com que dialoga com o leitor deixa explícito o papel da literatura; de outro modo, a confabulação com os temas sociais fica sob o signo do jornalismo, que é marcado pelas pautas de assuntos cotidianos, tais como o ressaltado na crônica "Inútil pranto por Santa Tereza", sobre a violência, um assunto corriqueiro nos jornais. Nesse sentido, a proposição de Candido (1989) é bastante elucidativa quanto ao tratamento que a crônica apresenta acerca dos assuntos:

Deixando de ser comentário mais ou menos argumentativo e expositivo, para virar uma conversa aparentemente fiada, foi como se a crônica pusesse de lado qualquer seriedade no tratamento de problemas (CANDIDO, 1989, s/d).

É imperioso considerar que o excerto de Candido corrobora a compreensão acerca da crônica de Caio. Isso porque, ao mesmo tempo em que as narrativas do escritor gaúcho têm como particularidades a oralidade e a percepção de assuntos cotidiano, também estão inseridas em um profundo significado dos atos e sentimentos humanos, estabelecendo, assim, uma crítica social a partir de diálogos com o leitor, haja vista que, quando o narrador incita o seu leitor a questionamentos, esse fica passível de refletir sobre as prerrogativas que estão sendo propostas.

No contexto em que Caio escreve para jornais e, de certa forma, dialoga com outros profissionais da área, é importante observar o que Arrigucci (1999) explicita sobre a influência que os jornalistas têm sobre a opinião pública:

Aí temos uma porção de aspectos. Primeiro que, de fato, as coisas a que o grande jornalista tem acesso, a importância que o jornal tem na formação da opinião pública, são de tal ordem que dão uma força, um poder extremo ao jornalista. Ele pode manipular a opinião pública. Isso não é pouco, é uma coisa enorme. E está tematizada lá, inclusive, no encontro do Sadat com industrias paulistas, em que os industriais não estão entendendo nada e o sujeito é que está canalizando os capitais da propaganda do sistema. Por outro lado, ele convive com as classes dominantes mesmo, exatamente porque ele tem uma parcela de poder nas mãos. Não um intelectual como Hugo Mann, que aspira a isso, que convive com essa gente, mas na verdade não está nessa posição (ARRIGUCCI, 1999, p. 86). ${ }^{5}$

É oportuno lembrar que Caio não é jornalista no sentido de repórter que escreve notícias e reportagens, mas, a partir do momento em que escreve suas crônicas, transporta-se a esse mundo e exerce influência sobre seus leitores, tornando-se narrador-repórter para usar uma expressão de Sá (2001) ao definir o perfil dos escritores de crônica. Com base nas premissas que circundam as crônicas 
analisadas nestas seções, é possível perceber que elas têm muitas coordenadas em comum no que tange especialmente à sua relação entre jornalismo e literatura: trazem à tona diversos fatos do cotidiano que não interessam ao jornal como objeto jornalístico, pois não se constituem de sua essencial matéria-prima: a informação. A crônica, por meio de assuntos e da linguagem, aproxima-se de seus leitores. Se comparada aos jornais, ela tem $o$ aspecto de maior subjetividade, que pode ser ressaltado pela linguagem e as reflexões utilizadas por Caio.

Outro aspecto significativo nas crônicas do escritor gaúcho é que esse vai de um assunto a outro, levando o leitor a variados temas, contudo, é singular na seleção de seus assuntos, baseia-se em um diálogo com o que está ocorrendo no social, mas transforma os assuntos de acordo com a sua visão, muitas vezes irônica e melancólica. Com um tom íntimo e coloquial, Caio se expõe ao leitor, são textos com ironia, um pouco de humor, mas carregados de introspecção, subjetividade, alusão a outros textos. Justamente por utilizar a sua visão para compreender o social, não tem uma teoria que dê conta de analisar as suas crônicas, já que essas vão muito além da linguagem coloquial, do humor e da ironia, da subjetividade e do diálogo com leitor.

\section{Chronicles of Caio Fernando Abreu: subjectivity and the search for dialogue with the reader}

\begin{abstract}
This paper examines chronic writer Caio Fernando Abreu, published in the newspaper Folha de São Paulo in the 1980s and 1990s and gathered in the book Life Shout to the Cantos, 2012. The proposal is to identify three peculiarities of chronic: subjectivity and the work of service in the chronicles, and the search for dialogue with the reader. The reading and interpretation of chronic Caio this work receives, as a methodological procedure, the articulation of form and content of the narratives in the critical perspective of the sociology of literature. By examining chronic Caio, it is observed that the gaucho writer narratives have as particularities orality and perception of everyday matters, are also inserted into a deep meaning of the acts and human feelings, thus providing a social critique from the dialogue with the reader, because when the narrator urges his reader to question, this is likely to reflect on the prerogatives through literary writing.
\end{abstract}

Keywords: Literature. Chronicle. Caio Fernando Abreu. Society. Memory. 


\section{Notas}

1 É importante considerar sobre o caráter autobiográfico as reflexões de Roland Barthes, já que o estudioso procurou conduzir os exercícios da análise literária para longe do biografismo, para outros rumos a que o texto se afirmasse como principal objeto a ser focalizado. "Em breve, vulgarizou-se e retomou força a noção de que o autor deveria ser afastado das preocupações analíticas, criando espaço para distinções essenciais entre autor e narrador, quando se tratava de romances e contos, e entre poeta e sujeito lírico, quando os textos em questão são poemas" (SIMON, 2008, p. 59). A percepção de Barthes torna-se importante para que as análises dos textos literários não se limitem a aspectos formais de narrador/autor, poeta/ sujeito lírico, mas sim, tenha maior riqueza com a intenção em outros aspectos.

2 Expressão que foi idealizada por Umberto Eco. O estudioso, em sua obra, "Lector de uma Fábula" admite que ao produzir um texto, o autor imagina como o leitor irá definir suas prerrogativas, contudo, ele não sabe ao certo como será interpretado, de como será esse leitor. E é neste contexto de produção e recepção que Eco cria a concepção de Leitor-Modelo.

3 Para melhor avaliar as condições de mercado em que o jornal estará inserido, uma estratégia que é utilizada, principalmente em grandes jornais, é a pesquisa de opinião pública. Esta apresenta resultados importantes, no que tange ao público-alvo, desde idade, classe social, dentre outros. Desse modo os jornalistas têm maior conhecimento a quem estão escrevendo.

4 Linha de apoio é uma expressão com cunho jornalístico. Representa, como o nome propõe, a linha colocada abaixo do título, para explicar o que o título deixou implícito. A linha de apoio pode também ser entendida como uma sucessora do lide, isto é, do primeiro parágrafo em que as principais informações da notícia/ reportagem devem ser expostas.

5 Fragmento retirado do livro Outros Achadose Perdidos, de uma seção de debates com Davi Arrigucci Jr., Carlos Vogt, Flávio Aguiar, Lúcia Teixeira Wisnik e João Luiz Lafetá.

6 Fragmento retirado do livro Outros Achados e Perdidos, de uma seção de debates com Davi Arrigucci Jr., Carlos Vogt, Flávio Aguiar, Lúcia Teixeira Wisnik e João Luiz Lafetá.

7 A expressão "narrador-repórter" é emprega nesta seção final do trabalho no sentido de que Caio contou histórias, explorando recursos estético-literários diversos, o que o aproxima do mundo da literatura, o que permite a adoção do termo "narrador" que alude mais diretamente à capacidade criativa. O termo "repórter" é usado para referenciar mais estreitamente o vínculo dos textos cronísticos do autor com o jornalismo. Enfim, "narrador-repórter" procura sintetizar o diálogo que a crônica de Caio estabelece entre literatura e jornalismo.

\section{Referências}

ABREU, Caio Fernando. A vida gritando nos cantos: crônicas inéditas em livro (19861996). Rio de Janeiro: Nova Fronteira, 2012.

ARRIGUCCI JÚNIOR, Davi. Outros achados e perdidos. São Paulo: Companhia das Letras, 1999.

BENDER, Flora Cristina; LAURITO, Ilka Brunhilde. Crônica: história, teoria e prática. São Paulo: Scipione, 1993.

CANDIDO, Antonio. A vida ao rés-do-chão, prefácio 5 da série. Para Gostar de ler: crônicas. Vários autores. São Paulo: Ática, 1989.

CORREA, Vanessa Loureiro. Língua portuguesa: da oralidade a escrita. Curitiba: IESDE, 2010.

COSTA, Alessandra Castilho. Tradições Discursivas em jornais paulistas de 1854 a 1901: Gêneros entre a história da língua e a história dos textos. GringVerlag, 2010. Disponível em: <https://books.google.com. $\mathrm{br} /$ books?id=59kKCGl2lCUC\&printsec $=$ fro ntcover\&hl=pt-BR\&source=gbs_ge_summary_r\&cad $=0 \# \mathrm{v}=$ onepage $\& \mathrm{q} \& \mathrm{f}=$ false $>$. Acesso em: 19 jul. 2013.

PELLEGRINI, Tânia. Despropósitos: estudos de ficção brasileira contemporânea. São Paulo: Annablume, 2008.

SÁ, Jorge de. A crônica. São Paulo: Ática, 2001.

SIMON, Luiz Carlos Santos. Vínculos entre a crônica e a autobiografia. In: SANTOS Volnei Edson (Org.). Sopros do Silêncio. Londrina: Eduel, 2008. p. 54-68. 